\title{
Observations on the Flora of Japan.
}

(Continued from vol. XXVI. p. 402.)

By

\author{
T. M a ki n o. \\ Lecturer of Botany in the Science College, \\ Imperial University of Tokyo.
}

Burmannia Itoana Makino, sp. nov. (Fig. I.)*

Burmannia sp. ITô, Mem. Work Bot. a. Zool. Commemor. Ninet. Anniv. K. I'Tô (KInkwa-Ô Kujû Gaju Hakubutsu KwaiShi), I. (1893), p. 14, tab. 2, fig. 1-2.

? Cryptonema malaccensis KR ̈̈̈ZL. in ENGLER's Bot. Jahrb. VI. (1885), p. 55 ; Matsum. Ind. Pl. Jap. II. 1(1905), p. 234, non TuRcz.

? Burmannia colestis C. H. Wright in Journ. Linn. Soc. XXXVI. p. 4 (1903) quoad pl. Amami-Osima. (leg. DöderLFin); Matsum. l. c., non D. Don.

A terrestrial plant, aphyllous, erect, small, about $5-13 \mathrm{~cm}$. in height, glabrous, cæruleo-violaceous; roots hypogæous, fibrous, thickly filiform, terete, simple, loosely fasciculate, radiate, glabrous, attaining $1 \mathrm{~mm}$. in diameter, with a filiform vascular: bundle in centre. Stem solitary, gracile, slender, terete smooth, simple, or furnished with the erect 1-3-branches above pale in hypogæous portion towards the base, about $\frac{4}{5}-1 \frac{1}{2} \mathrm{~mm}$. across. Scales sparse on the stem throughout, small, rather closely placed and smaller in the basal ones, but the rest very remotely placed, adpressed or erect-patent, membranaceous, amplexicaul, ovato-deltoid, elliptical, ovate, or ovatosemiorbicular, entire, obtuse, cucullato-fornicate at the obtuse apex and subconduplicate and carinate dorsally in the superior ones, 1-nerved, about $2-5 \mathrm{~mm}$. long, with a young flower-bud, which at length not developed, in the axil; those under the

\footnotetext{
* Figure will appear in the fore-coming number 315.
} 
flower bract-like, protecting the flower-bud, often 2, alternate, approximate, shorter than the flower, erect or erect-patent, membranaceous, elliptical to elliptical-oblong, obtuse, entire, conduplicate, carinate dorsally, 1-nerved, 4-5 mm. long. Flower erect, terminal, $8-9 \mathrm{~mm}$. long, longitudinally 3-winged, broadly acute at the base and continued to the pedicel which is the top of the main stem and branches. Perianth superior, erect, straight; limb small, much shorter than the tube, 6-lobed; external-lobes 3, small, erect, ovato-deltoid, subrhombic towards the base, obtuse, entire, thick, nearly plane dorsally, thicker and convex towards the centre internally, 1 -nerved, about $1 \frac{1}{2} \mathrm{~mm}$. long, $1 \frac{1}{4} \mathrm{~mm}$. broad, induplicato-valvate in bud; interior-lobes 3 , much smaller and minute, erect, depressed-deltoid, entire, thick, about $\frac{1}{5} \mathrm{~mm}$. long; tube broadly cylindrical, often somewhat enlarged below, about $4 \mathrm{~mm}$. long, $2 \frac{1}{2} \mathrm{~mm}$. across, membranaceous, longitudinally 6-nerved; wings membranaceous, cuneate, entire, obliquely obtuso-truncate at the apex, shorter than the floral body and about 5-6 $\mathrm{mm}$. long, $1 \frac{1}{2}-2 \mathrm{~mm}$. broad. Stamens 3, sessile, inserted in a short distance under the throat, opposite to the interior-lobes of perianth, lower than the stigmas; anther-cells remote by the horizontal connective, transversely oblong, scarcely 2-lobed, about $\frac{1}{2} \mathrm{~mm}$. broad, separating the inside into 2 loculaments by a vertical dissepiment, longitudinally dehiscing; connective stout, thick, longer than the anther-cells, with the minutely papillose processes at the base, the superior appendage 2-parted and the inferior one integral. Style erect, springing from the thickened truncate top of the ovary, included, just reaching to the throat of perianth, $4 \mathrm{~mm}$. long, rathar stout, straight, terete, smooth, 3-nerved ; arms short, thick, erect-patent, enlarged towards the stigma: stigmas 3, large, dilated, truncate, orbiculate, disciform, directing outwards, $1 \mathrm{~mm}$. across. Ovary inferior, obovato-globular, 3-ridged, about $3 \mathrm{~mm}$. long, 3-celled, with very numerous ovules; ovules minute, densely attached to the thick 2-parted prominent axile placentas, obovatooblong or obovato-fusiform, obtuse at the apex, with a funicule which is shorter than the ovule, about $\frac{1}{3} \mathrm{~mm}$. long. Capsule 
crowned by the marcescent perianth, globular, about $3 \mathrm{~mm}$. across, with membranaceous carpels, transversely ruptured between the ridges. Seeds very numerous, minute, oblong, elliptical, or fusiform, yellow, about $\frac{1}{3} \mathrm{~mm}$. long ; testa thin, inconspicuously reticulated, slightly loose; embryo obovately oblong or elliptical, cellular, a little shorter than testa.

Nom. Jap. Ruri-shakudyô, Yayeyama-shakudyô.

Hab. YAYEXAMA ARCHIP.: Mt. Fazan in Ôkawa-mura, Isl. Ishikaki (Setsusaburô Tanaka, June 28, 1891) ; LIUKIU : Nago-mura in Kunchan-gôri, Isl. Okinawa (Yoyemon Nakano! Aug. 9, 1912).

Burmannia cryptopetala MaKino, sp. nov. (Fig. II.)* A terrestrial plant, about $6-17 \mathrm{~cm}$. high, erect, aphyllous, white, glabrous ; roots hypogæous, fibrous, fasciculate, radiate, filiform and often thickish, terete, glabrous, simple or very loosely ramose with patent branches, with a filiform vascularbundle in centre. Stem solitary, slender, often rather stout, simple, or rarely 1-branched above, terete, smooth, diaphanous, $\frac{3}{4}-1 \frac{3}{4} \mathrm{~mm}$. across. Scales small, distichously or subsparsely alternate on the stem throughout, remote but closely placed at the base, adpressed or erect-patent, $1 \frac{1}{2}-6 \mathrm{~mm}$. long, amplexicaul, each with a young flower, which at length not developed, in the axil, ovate to ovato-subulate, obtuse- or acutish-tipped, entire, membranaceous, 1-nerved; the superior ones subconduplicate and subcarinate dorsally, subfornicate at the apex. Cyme with 2-7-flowers, or 1-flowered ; rachises of the cyme dichotomously 2 , secundly $1-3-$ flowered, attaining about $1 \mathrm{~cm}$. in length, stright, erect-patent or neariy erect, rather stout, angulate; pedicels short or very so, straight, 1-2 mm. long, triquetrous ; bracts laxly placed, scaly, adpressed or erect-patent, about 4-6 mm. long, amplexicaul, membranaceous, 1-nerved, subulate or oblong-subulate, obtuse to acuminate at the apex, obscurely serrulate, carinate dorsally. Flowers erect, close each other, acute and continued to the pedicel at the base,

* Figure will appear in the fore-coming number 315 . 
longitudinally 3-winged, 8-11 mm. long. Perianth superior, erect, straight; limb yellow, small, much shorter than the tube, 6-lobed or sub-6-lobed or 3-lobed; external lobes 3, subrecurvo-erectpatent, induplicato-valvate in bud, broadly ovatodeltoid, obtuse- or acutish-tipped, entire, thicker and very minutely papillose towards the margin, thinner in centre, slightly concave internally, alato-carinate dorsally, 1-nerved, about $1 \frac{1}{2} \mathrm{~mm}$. long, $1 \frac{1}{2}-1 \frac{3}{4} \mathrm{~mm}$. wide; interior lobes very minute and depressed, or obscure, or none; tube straight, shortly cylindrical, abruptly slightly enlarged at the apex which continued to the limb, gradually somewhat enlarged towards the base which is continued to the ovary, membranaceous, longitudinally $6-$ nerved, about $3-3 \frac{1}{2} \mathrm{~mm}$. long, $1 \frac{1}{2}-2 \mathrm{~mm}$. across; wings shorter than the floral body, membranaceous, entire-margined, cuneate, obliquely subrtuncate and narrowly adnate to the back of the exterior lobes of the limb at the apex, gradually narrowed and decurrent to the pedicel, $13^{3}-3 \mathrm{~mm}$. broad. Stamens 3, inserted in a short distance under the throat, opposite to the interior lobes of perianth, slightly lower than the stigmas, sessile; anther-cells disconnected and remote by a transverse stout connective, transversely ellipsoid, separating the inside into 2 loculaments by a vertical dissepiment, transversely dehiscing; connective horizontal, thick, somewhat broader than the anther-cells towards the middle, with a small conical process on the upper side, prominent on the middle of the front face and adherent to the style-arms. Style included, erect, springing from the obtuse top of the ovary, stout, terete, smooth, 3 -nerved, very shortly 3 -fid into 3 erect-patent arms at the top ; stigmas 3 , terminal, large, $1 \mathrm{~mm}$. across, transversely subglobosoellipsoid, broadly marginate with a lunato-semiorbiculate dilated appendage externally, very deeply hollow with a small short and broad lid (which is smaller than dimensions of the mouth) from the inner margin in the elliptical mouth, which open outwards. Ovary inferior, a little longer than the perianth-tube, narrowly 3 -alate by the decurrence of the wings, oval to oblong-ellipsoid, 3 -celled with very thinly membranaceous dissepiments, about $3-5 \mathrm{~mm}$. long, $2-3 \mathrm{~mm}$. across ; ovules very numerous, minute, 
fusiform, about $3-\frac{1}{5} \mathrm{~mm}$. long, attached to the 2-parted prominent axile placentas with a funicule. Capsule crowned by the marcescent perianth, oval to ellipsoid, $2-3 \mathrm{~mm}$. across, with membranaceous carpels, irregularly transversely ruptured. Seeds very numerous, minute, yellow but ferruginous towards the top, fusiform, $\frac{1}{3}-\frac{1}{2} \mathrm{~mm}$. long; testa loose at the apex, subreticulato-striate; embryo ellipsoid to narrowly oblong.

Nom. Jap. Shiro-shakudyô (nov.).

Hab. Prov. YAMASHIRO: Kamigamo (T. Makino!; S. Agô !); Prov. ISE : Yamada (T. Makino!); Prov. HIZEN : Isahaya (Z. TAshiro! Dec. 3, 1911.) ; Prov. KII : Mt. Nachi (K. Minakata! herb. Sc. Coll. Imp. Univ. Tokyo, 1903).

(To be continuted.) 